\title{
Verskillende wêrelde teen die lig gehou
}

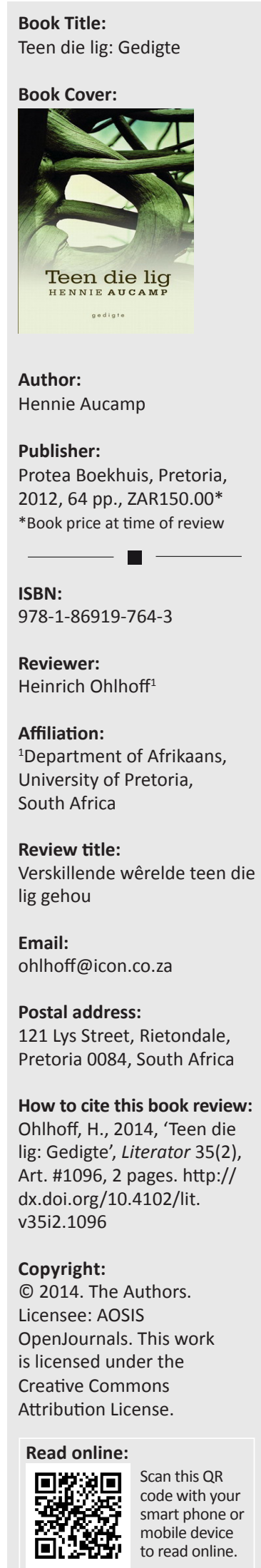

'n Boeiende leeservaring. Só sou 'n mens Hennie Aucamp se jongste digbundel, opgedra aan Johann de Lange, kon tipeer - nie omdat dit diepsinnig filosofies wil wees nie, maar omdat dit in taal verskillende wêrelde 'teen die lig hou' en voor die leser laat oopgaan: 'n vergange jeugwêreld, die wêreld van kuns en kunstenaars, die wêreld van die vroegste bewoners van SuidAfrika, die wêreld van hulle wat nie meer daar is nie ...

In sekere opsigte bied die openingsgedigte, 'Nature morte' en 'Proses', sleutels tot die bundel: As beeldgedig vang eersgenoemde iets vas van 'n spesifieke kunsvorm, naamlik die stillewe, en die plek van die kunstenaar in die totstandkoming daarvan: Hy moet dit as 't ware ontdek: 'Die ware stillewe/word nie opgestel nie:/Dit wag reeds op die kunstenaar'. In die tweede strofe word dan aangesluit by die aard van stillewes in die algemeen, terwyl strofe drie die leser se aandag op 'n spesifieke kunswerk vestig ('dié stillewe', met verwysing na Jan Voerman se akwarel wat in die subtitel ter sprake is). En dan die slotsom in die slotstrofe waar ' $n$ leitmotief van die bundel - verganklikheid - reeds begin figureer: 'Die ware stillewe/is 'n essay:/altyd metafisies, altyd/ deurtrokke van sterflikheid. 'Proses' is metatekstueel van aard en ook'n herskrywing van Cussons se baie langer 'Teesuiker'. By Aucamp gaan dit naamlik oor die organiese totstandkoming van 'n storie waar 'n 'storietjie' met min inhoud oor 'n glas laat sak word 'waar in 'n stroopsoet mengsel/kristalle daaraan pak//en klont en knoets en eindelik/—o lieflike gesig —/'n simpel storiedraadjie/tot teesuiker verdig'.

Op hierdie openingsgedigte volg vier afdelings, elk met ' $n$ duidelike fokus, dog gebind deur enkele leitmotiewe soos die genoemde dood en verganklikheid - maar nie noodwendig op 'n somber noot nie. Die eerste afdeling sentreer grootliks om die familieplaas 'Rust-mijn-ziel' 'n bekende gegewe in Aucamp se oeuvre - en put uit en rekonstrueer persoonlike, familie- en kulturele geheue. Reeds van die titels laat dit blyk: 'Bakdag op Rust-mijn-ziel', 'Skeertyd op Rust-mijn-ziel', 'Ma se resepteboek', 'Ouma se dagboek', 'Die blomme van 'n kindertyd'... Met uitsondering van die 'Gesondheid in die rondheid'-reeks wat uit kwatryne bestaan, word die res van hierdie afdeling, behalwe die 'stertsonnet' ( 'Spyskaart') met sy ekstra kwatryn, gevorm deur Shakespeariaanse sonnette met hul tipiese sluiting ('closure') van die een of ander aard in die slotkoeplet. So byvoorbeeld 'Slagdag op Rust-mijn-ziel': 'Almal is dood, net ek is nog hier,/ om 'n plaas en sy vreugdes met woorde te vier'. Wat dan inderdaad in hierdie afdeling gebeur, byvoorbeeld in die Persiese kwatryn 'Heildronk op 'n Nuwe Geslag' waarin Gorter se Mei betrek word: 'Lig, soos 'n Gorter, jou kristalhelder fluit/op 'n nuwe lente en 'n nuwe geluid;/die oesjaar was goed: Hou die borrels dop,/ hoe hulle, ekstaties, op voleindiging stuit'.

Soos die openingsgedigte suggereer, en nie vreemd in Aucamp se oeuvre nie, bevat die tweede afdeling gedigte oor kunsvorme soos die musiek en die letterkunde. Dit begin met die reeks 'Aan die musiek' waardeur ingespeel word op Schubert se gelyknamige lied. Die musiek wissel egter van Vivaldi en Bach tot kermiswalsmusiek en 'Boeretroos'. Hier is veral 'Johann Sebastian' treffend wat die einde van die aarde, "n Opgebruikte ster' kontrasteer met dit wat sal duur: 'sal iets astraals behoue bly,/'n oergeheime krag/wat náklink in die ruimte:/die fugas van 'n Bach'. Daarna volg die reeks 'O aarde, ryk aan bome', maar steeds binne 'n kulturele en kunskonteks: 'Geen kunstenaar kan beeldhou/soos die oernatuur...' Die titel van die reeks 'Die sneeu van voorverlede jaar' roep die ballade van Francois Villon (en tekste van onder meer Krige en Breytenbach) op. Die eerste en derde teks waarin 'Fransoois' aangespreek word, word geskei deur ses kwatryne oor kunstenaars en 'n gimnas waarin aftakeling en verganklikheid ook telkens deurklink, byvoorbeeld in 'Ballerina': 'Eenmaal was sy ligvoets/met wimperskadu's op haar wang,/nou kyk sy uit 'n rolstoel/hoe tuinvoëls vlinders vang'. Die afdeling sluit af met 'Diereriem' waarin (her)interpretasies van en reaksies op dié sterretekens in kwatryne verwoord word.

Afdeling drie delf in die oergeskiedenis van Suid-Afrika, sy inheemse diere en mense en hul oorlewerings. So kom die skilpad ter sprake wat 'n intertekstuele gesprek voer met onder meer Ernst van Heerden se skilpad-gedig, terwyl liggaamlikheid as 'eiendomsmerk' op besondere 
manier in 'Boesman-ID' figureer: 'Sy handdruk teen 'n rotswand/wou nooit 'n rots versier;/bevestig bloot, en oor en oor:/Eenmaal was ek lyflik hier'. Hierdeur sluit dit aan by die slotkoeplet van 'Rotsgravures': 'En só skryf Afrika sy kaart en transport/op blaaie wat nie in die tyd verword'. Teenoor hierdie 'tydloosheid' staan daar egter ook hier gedigte wat van dood en verganklikheid getuig, 'n motief wat in die slotafdeling ' $n$ hoogtepunt bereik met ' $n$ groep gedigte oor begrafnis en gestorwenes soos George Weideman. Laasgenoemde, ' $n$ eerbetoon, toon ' $n$ vernuftige spel met grond, voedsel en poësie: 'Hy druk sy ploeg in barre aarde/en haal baroe na bo;/en dit kan net as grondiglik/'n digter aan sy woorde glo'. Hierdie afdeling en die bundel loop dan gepas uit op die speelse, meerduidige 'Aandlied' (wat Ina Rousseau se veel wranger gedig met ' $n$ verwante titel oproep):
Dood kom oor die bulte,/'n ou man in 'n kros,/en is hy in die leegte/moet ek my pen laat los/en eers ons padkos regkry/die ou sal honger wees, gewis - / twee flessies duineheuning,/'n broodjie en 'n vis.

Ons het hier 'n bundel wat met 'tradisionele middele' werk: rym, strofes, sonnette, kwatryne ... wat, sou 'n mens kon sê, die nostalgie en terugkyk wat so kenmerkend van baie van die gedigte is, ondersteun. Dit geld ook die 'verouderde' gebruik van 'o' en die argaïese en streektaalwoorde. Die tekste is op die oog af eenvoudig, maar die skyn bedrieg: Deur die funksionele digvorme, die fyn, gevoelige woordgebruik en deur die intertekstuele netwerk wat geskep word, kom 'n rykdom aan betekenis tot stand en kom daar met elke herlees nuwe nuanses na vore. 